\title{
PENGARUH MODEL PEMBELAJARAN JIGSAW DAN STAD TERHADAP HASIL BELAJAR PUISI PADA SISWA KELAS VIII SMP NEGERI 19 MEDAN TAHUN PELAJARAN 2018/2019
}

\author{
Lasroha Marito Simanullang, Roma Ito Purba, Nasrah Bancin, Oktaviandi Bertua Pardede \\ Prodi Pendidikan Bahasa dan Sastra Indonesia. \\ Fakultas Keguruan dan Ilmu Pendidikan. \\ Email: lasrohasimanullang11@gmail.com, purbaromaito@gmail.com, Nazrahyhani@gmail.com, \\ oktaviandibertuapardede@unprimdn.ac.id
}

\begin{abstract}
Abstrak
Tujuan penelitian ini adalah untuk mengetahui pengaruh antara penggunaan model pembelajaran kooperatif tipe Jigsaw, STAD dan Konvensional pada hasil belajar puisi oleh siswa. Penelitian ini menggunakan metode kuantitatif dengan pendekatan eksperimen. Populasi dalam penelitian ini adalah siswa Kelas VIII SMP Negeri 19 Medan. Teknik pengambilan sampling menggunakan teknik random sampling. Dalam penelitian ini yang menjadi sampel penelitian adalah siswa-siswi kelas VIII SMP Negeri 19 Medan, setiap kelas ada 34-35 siswa yang di pilih untuk eksperimen pembanding adalah tiga kelas. Hasil uji hipotesis menunjukkan ada perbedaan pengaruh yang signifikan antara model pembelajaran Stad dengan konvensional terhadap hasil belajar puisi. Hal ini dibuktikan dari harga Fhitung sebesar 3,230. Diperoleh bahwa sig $<\alpha$ yakni $0,044<0,05$ maka dapat disimpulkan bahwa hipotesis yang diterima adalah Ha. Dapat diketahui bahwa harga sig yang diperoleh maing-masing pasangan yaitu 0,884 (Jigsaw-Stad), 0,436 (Jigsaw-konvensional) dan 0,039 (Stad-konvensional). Untuk mengetahui kriteria apa yang dimiliki setiap pasangan maka dibandingkanlah sig dengan $\alpha$. Untuk Jigsaw-Stad $(0.884>$ $0,05)$, Jigsaw-koonvensional $(0,436>0,05)$ dan Stad-konvensional $(0,039<0,05)$. Dengan demikian dapat diketahui bahwa pasangan Jigsaw-Stad menerima H0, pasangan Jigsaw-konvensional menerima H0 dan hanya pasangan Stad-konvensional saja yang menerima Ha. Jadi dapat disimpulkan penerapan model Stad berpengaruh pada hasil belajar puisi di kelas VIII SMP Negeri 19 Medan Tahun Ajaran 2018/2019. Kata kunci: Pengaruh Model Pembelajaran Jigsaw, Stad, Hasil Belajar Puisi
\end{abstract}

\begin{abstract}
Abstrac
The purpose of this study is to find out the influence between the use of the cooperative learning model of the jigsaw type. Stad and the conventional practice of learning poetey by the students. The study is using a quantitative method of approach. The population in this study is eighth grade at 19 countries' high school. The sampling is an random sampling technique. In this study the 34-35 students selected for the appeals were from 19 state middle school eight class. Each class 34-35 students selected for advertising experiment were three classes. The suggested hypothetical test indicates a significant difference of influence between the learning model stad and the conventional out come of the study of poetry. This is evidenced by the calculation price of 3.230. Either her a sig $<\alpha 0,044<0,05$ is decuded that the received hypothesis is Ha. It can be noted that the price of a sig by couple was 0,884 (JigsawStad), 0,436 (Jigsaw-conventional) and 0.039 (Stad-conventional). To know the criteria of what is held evwry audience member then passed to the sourced by $\alpha$. For jigsaw-stad $(0,884>0,05)$. Jigsawconventional $(0,436>0,05)$ and Stad-conventional $(039<0,05)$, that is possible to note the Stadconventional couple received $\mathrm{Ha}$. So, in summary the application of the model stated has a effect on learning poetry in the eighth grade of the 19th land junior high school year 2018/2019.
\end{abstract}

Keywords: Influence Of The Jigsaw Learning Model, Stad, Poetry Learning Results

\section{PENDAHULUAN}

Bahasa Indonesia merupakan salah satu mata pelajaran yang diajarkan pada tingkatan Sekolah Menengah Pertama (SMP). Pada tingkatan ini pelajaran Bahasa Indonesia telah mencakup 4 klasifikasi capaian kebahasaan yaitu menyimak, berbicara, membaca dan menulis. Keempat komponen tersebut mutlak diperoleh oleh siswa SMP, karena pada tahapan ini siswa sudah berada pada kriteria mampu untuk menerapkan hingga menjelaskan hubungan antara objek dan subjek kebahasaan.

Sebagaimana telah dikemukakan oleh Abrams (dalam Nurgyantoro, 2009: 4) disebut "beberapa ragam karya sastra seperti fiksi historis (historcal fiction) jika penulisannya berdasarkan fakta sejarah, fiksi biografis (biografical fiction) jika berdasarkan fakta biografis, dan fiksi sains sains (science fiction) jika penulisannya berdasarkan pada ilmu pengetahuan". Dan kekompleksitasan karya sastra ini juga dipertegas oleh Sumardjo dan Saini (1997: 18-19) bahwa "karya sastra diklasifikasikan atas sastra nonimajinatif dan sastra imajinatif dan kemudian diturunkan hingga karya berupa surat-menyurat dan drama puisi atau prosa". Menurut Sugihastuti (2007: 81 - 82) karya sastra merupakan "Media yang digunakan oleh pengarang untuk menyampaikan gagasan-gagasan dan pengalamannya". Sebagai media, peran karya 
sastra sebagai media untuk menghubungkan pikiran-pikiran pengarang untuk disampaikan kepada pembaca. Selain itu, karya sastra juga dapat merefleksikan pandangan pengarang terhadap berbagai masalah yang diamati di lingkungannya.

Terkait dengan hal tersebut maka tim peneliti telah melakukan observasi awal di SMP Negeri 19 Medan. Diketahui bahwa hasil belajar karya sastra oleh siswa masih berada pada rata-rata yang sama. Kemudian banyak keluhan mengenai minimnya pembekalan atau kegiatan peningkatan keterampilan bersastra siswa juga menjadi alasan mengapa sastra tidak muncul sebagai ikon bahasa Indonesia. Selain itu pembelajaran yang diterapkan oleh guru bahasa Indonesia juga masih didominasi oleh model pembelajaran konvensional. Minimnya motivasi belajar dan keberagaman daya serap siswa terhadap pengajaran guru juga menjadi kendala dalam pelajaran Bahasa Indonesia. Serta ketidakefektifan model pembelajaran yang diterapkan oleh guru dalam pembelajaran memahami karya sastra. Oleh karena itu untuk mencari jalan keluarnya perlu dilakukan pendekatan perbaikan pada sistem pengajaran, salah satunya yaitu melalui pemilihan model pembelajaran yang tepat oleh guru.

Menurut Istarani (2017:1) model pembelajaran adalah "seluruh rangkaian penyajian materi ajar yang meliputi segala aspek sebelum, sedang dan sesudah pembelajaran yang dilakukan guru serta segala fasilitas yang terkait yang digunakan secara langsung atau tidak langsung dalam proses belajar mengajar". Model pembelajaran juga sebagai suatu desain yang menggambarkan proses rincian dan penciptaan situasi lingkungan yang memungkinkan siswa berinteraksi sehingga terjadi perubahan atau perkembangan pada diri siswa.

Pemilihan model pembelajaran kooperatif diharapkan dapat menunjang interaksi antara siswa dengan siswa atau antara siswa dengan guru, dalam penelitian ini akan diteliti dua model pembelajaran kooperatif, diantaranya adalah model pembelajaran kooperatif tipe Jigsaw dan tipe STAD (Student Teams Achievment Division). Pada penelitian ini model pembelajaran konvensional akan dibandingkan dengan bersama-sama pada kedua model tersebut.

Berdasarkan uraian tersebut maka peneliti akan mengadakan penelitian dengan melakukan pengembangan pembelajaran kooperatif tipe Jigsaw dan STAD. Kedua model pembelajaran ini digunakan untuk mengetahui komposisi mana yang lebih cocok dalam mengoptimalkan pelajaran Bahasa Indonesia. Menurut Donni Juni Priansa (2017:341) Pembelajaran kooperatif tipe Jigsaw merupakan salah satu tipe pembelajaran yang kooperatif dan fleksibel. Dalam pembelajaran tipe Jigsaw, peserta didik dibagi menjadi kelompok-kelompok yang anggotanya mempunyai karakteristik heterogen. Keunggulan pembelajaran tipe Jigsaw ini adalah meningkatkan rasa tanggung jawab siswa terhadap pembelajarannya sendiri dan juga pembelajaran orang lain, siswa tidak hanya mempelajari materi yang diberikan, tetapi juga harus memberikan dan mengajarkan materi tersebut kepada orang lain yaitu anggota kelompoknya yang lain.

Sedangkan model pembelajaran tipe $S T A D$ ini merupakan model pembelajaran kooperatif, siswa belajar dengan cara membentuk kelompok yang anggotanya 4-5 orang siswa secara heterogen, setelah guru memberikan tugas kepada kelompok setiap anggota kelompok akan berusaha mempelajarinya dan yang sudah bisa memahami materi membantu anggota yang lain. Keunggulan pembelajaran tipe STAD ini adalah adanya kerjasama dalam kelompok dan dalam menentukan keberhasilan kelompok, tergantung keberhasilan individu.

Untuk mengetahui apakah ada perbedaan pencapaian hasil belajar puisi dengan penggunaan model pembelajaran kooperatif tipe Jigsaw dan kooperatif tipe STAD bersama-sama dengan model pembelajaran konvensional di sekolah tersebut, berdasarkan masalah yang telah dipaparkan sebelumnya, maka terdapat beberapa masalah yang perlu diteliti yaitu:

1. Hasil belajar puisi oleh siswa belum menunjukkan peningkatan yang signifikan.

2. Banyak keluhan mengenai minimnya pembekalan atau kegiatan peningkatan keterampilan bersastra siswa

3. Pembelajaran yang diterapkan oleh guru bahasa Indonesia masih didominasi oleh model pembelajaran konvensional.

4. Minimnya motivasi belajar dan keberagaman daya serap siswa terhadap pengajaran guru.

5. Ketidakefektivitasan model pembelajaran yang diterapkan oleh guru dalam pembelajaran memahami msteri puisi.

\section{METODE PENELITIAN}

Lokasi penelitian yang akan diteliti adalah di SMP Negeri 19 Medan, Kecamatan Medan Petisah, dimana populasi penelitian ini merupakan siswa SMP Negeri 19 Medan Kelas VIII. Adapun jumlah sampel yang akan direduksi melalui teknik penarikan sampel dengan cara simple random sampling. Teknik penarikan sampel ini pada dasarnya mencari sampel dari populasi kelas yang telah diparalelkan dan populasinya homogen. Secara teoritis simple random sampling adalah teknik yang digunakan dengan cara mengundi (acak tanpa memperhatikan strata) untuk memperoleh sampel dari populasi yang 
anggotanya homogen (Sugiyono, 2014 :120). Oleh karena itu sesuai dengan paradigma yang dikemukakan dalam rumusan masalah maka dari kelas paralel diundi untuk diambil tiga kelas (sampel) yaitu kelas VIII-1, VIII-2, VIII-3 yang berjumlah keseluruhan siswa 103.

a. Variabel Penelitian

Variabel bebas dalam penelitian ini adalah dengan model pembelajaran. Sedangkan variabel terikat dalam penelitian ini adalah hasil belajar siswa dalam pembelajaran puisi.

b. Jenis dan Desain Penelitian

Penelitian ini melibatkan tiga kelas dan diberi perlakuan berbeda. Penelitian ini akan dilakukan dengan metode quasi eksperimen. Ketiga kelas akan dieksperimen dengan perlakukan yang berbeda yaitu dengan pengajaran dengan menggunakan model pembelajaran konvensional, model pembelajaran Jigsaw dan model pembelajaran STAD. Sehingga kelas kontrol dan kelas eksperimen tidak difungsikan secara metodologis dalam penelitian ini.

Untuk mengetahui hasil belajar siswa yang diperoleh dengan menerapkan tiga perlakuan tersebut maka setiap siswa akan diberikan tes tentang materi puisi (pilihan ganda dan uraian). Sesuai dengan tujuan penelitian, maka untuk mendapatkan data dilakukan penelitian yang bersifat eksperimen. Agar kedua kelas homogen maka proses penelitian ini dilaksanakan melalui tahap berikut:

1. Ketiga kelas diberi tes awal

2. Ketiga kelas diberi materi yang sama

3. Alokasi waktu pembelajaran materi relatif sama

4. Guru yang menyampaikan materi adalah guru yang sama dan peneliti.

5. Perbedaan hanya terletak pada perlakuan yaitu pembelajaran menggunakan model pembelajaran konvensional, model pembelajaran jigsaw dan model pembelajaran STAD.

c. Prosedur penelitian

Untuk melaksanakan penelitian ini, ditempuh langkah-langkah sebagai berikut:

1. Tahap persiapan

2. Tahap pelaksanaan

3. Tahap pengumpulan data

d. Alat dan Pengumpulan Data

Sebagai alat pengumpul data dalam penelitian ini digunakan tes bentuk pilihan berganda sebanyak 20 soal dan bentuk uraian sebanyak 5 soal. Karena banyaknya klasifikasi karya sastra maka penelitian mereduksi materi karya sastra yaitu tentang puisi. Menurut Aminuddin (2015:134) Puisi berasal dari bahasa Yunani pocima "membuat" atau poeisis "pembuatan" dan dalam bahasa inggris disebut poem atau poetry. Puisi diartikan membuat dan pembuatan karena lewat puisi pada dasarnya seorang telah menciptakan suatu dunia tersendiri, yang mungkin berisi pesan atau gambaran suasanasuasana tertentu, baik fisik maupun batiniah. Sebelum tes tersebut digunakan sebagai alat pengumpul data terlebih dahulu divalidasi oleh validator/ para ahli yang bertujuan untuk mengetahui kelayakan instrumen.

Kriteria penilaian untuk setiap soal pilihan ganda yang dijawab benar akan diberi skor 1 dan salah akan diberi skor 0 . Sedangkan untuk soal uraian objektif setiap nomor diberi rentang skor 0 untuk tidak menjawab, 1 untuk jawaban tidak tepat, 2 untuk jawaban kurang tepat, 3 untuk jawaban cukup tepat, 4 untuk jawaban tepat. Selanjutnya jumlah total skor dari setiap siswa dikonversikan kedalam bentuk nilai dengan menggunakan rumus sebagai berikut :

$$
\text { Nilai }=\frac{\text { Jumlah Skor Jawaban }}{\text { Jumlah Skor Total }} \times 100
$$

Karena terdapat dua bentuk instrumen yang digunakan maka nilai yang diperoleh masing-masing dikonversikan lagi dengan menggunakan rumus berikut ini:

$$
\text { Nilai }=(35 \% \text { x Nilai pilihan ganda })+(65 \% \text { Nilai uraian })
$$

Untuk mengetahui kategori kemampuan siswa, maka terlebih dahulu menentukan kriteria yang akan dijadikan dasar untuk mengambil kesimpulan seperti yang ada pada tabel berikut ini:

Tabel 2.3. Kategori Kemampuan Siswa

\begin{tabular}{|l|l|}
\hline Interval & Kriteria \\
\hline $80-100$ & Baik Sekali \\
\hline $60-79$ & Baik \\
\hline $40-59$ & Cukup \\
\hline $30-39$ & Kurang \\
\hline $0-29$ & Gagal \\
\hline
\end{tabular}

e. Teknik Analisis

Teknik analisis data yang digunakan adalah teknik statistik deskriptif dan inferensial. Teknik statistik deskriptif digunakan untuk mendeskripsikan data, antara lain nilai rata-rata (mean), simpangan 
baku, median, dan modus. Dan teknik statistik inferensial digunakan untuk menguji hipotesis penelitian. Teknik inferensial yang akan digunakan dalam penelitian ini adalah uji kesamaan lebih dari dua rata-rata atau analisis varians (anava) satu jalur dengan menggunakan "uji-F". Sebelum dan setelah model pembelajaran diterapkan maka sebelum uji-F digunakan terlebih dahulu menghitung uji normalitas dan homogenitas varians ketiga kelompok sampel baik pada pretes maupun postes. Namun sebelum menghitung uji normalitas dan homogenitas varians kedua kelompok sampel dengan tes awal, terlebih dahulu menghitung rata-rata, median, modus, standar deviasi atau simpangan baku.

\section{PEMBAHASAN DAN HASIL}

Hasil penelitian ini diperoleh berdasarkan metode yang telah dipaparkan dalam bab sebelumnya. Pendeskripsian data penelitian bertujuan memberikan gambaran aktivitas penelitian melalui parameter yang telah ditentukan. Perlu diketahui juga bahwa instrumen yang digunakan dalam penelitian ini telah melalui ujicoba oleh para ahli, sehingga data hasil penelitian yang diperoleh berasal dari alat ukur yang valid dan reliabel. Untuk itu pada lampiran laporan dapat dibuktikan hasil uji coba instrumennya.

Penelitian di SMP Negeri 19 Medan ini dilaksanakan berdasarkan arahan dan kesepakatan dengan kepala sekolah dan guru bahasa Indonesia bersama dengan para peneliti. Sesuai dengan tujuan penelitian maka terlebih dahulu dideskripsikan hasil penelitian pada masing-masing model pembelajaran yaitu sebagai berikut:

Tabel 3.1. Deskripsi Data Hasil Penelitian melalui SPSS

\begin{tabular}{|c|c|c|c|}
\hline \multicolumn{3}{|c|}{ Model Pembelajaran } & Statistic \\
\hline \multirow{18}{*}{$\begin{array}{c}\text { Data hasil belajar } \\
\text { Puisi }\end{array}$} & \multirow[t]{6}{*}{ model jigsaw } & Mean & 70,24 \\
\hline & & Median & 70,00 \\
\hline & & Variance & 30,428 \\
\hline & & Std. Deviation & 5,516 \\
\hline & & Minimum & 58 \\
\hline & & Maximum & 80 \\
\hline & \multirow[t]{6}{*}{ model STAD } & Mean & 71,71 \\
\hline & & Median & 70,00 \\
\hline & & Variance & 38,517 \\
\hline & & Std. Deviation & 6,206 \\
\hline & & Minimum & 60 \\
\hline & & Maximum & 82 \\
\hline & \multirow{6}{*}{$\begin{array}{c}\text { model } \\
\text { Konvensional }\end{array}$} & Mean & 68,20 \\
\hline & & Median & 69,00 \\
\hline & & Variance & 30,576 \\
\hline & & Std. Deviation & 5,530 \\
\hline & & Minimum & 60 \\
\hline & & Maximum & 78 \\
\hline
\end{tabular}

Deskripsian data hasil penelitian diukur melalui 6 parameternya. Dan berdasarkan analisis melalui SPSS tampak bahwa rata-rata hasil belajar puisi yang menggunakan model STAD lebih tinggi dari dua model lainnya, dan hasil belajar yang rata-ratanya paling rendah adalah model pembelajaran konvensional. Namun jika ditinjau deri parameter lainnya ternyata nilai terendah tidak berada pada data kelas yang diajar dengan model konvensional melainkan di kelas yang diajar dengan model jigsaw. Demikian pula penyimpangan data (standart deviation), ternyata sebaran data hasil belajar yang paling besar terletak pada kelas yang rata-ratanya paling tinggi yaitu model STAD. Hal ini tentu menggambarkan bahwa sampel (siswa) yang diteliti memiliki kecenderungan karakter belajar yang tinggi. Oleh karena itu selanjutnya perlu dilakukan pengujian agar kesimpulan penelitian ini lebih signifikan.

a. Uji Normalitas

Uji normalitas dalam penelitian ini bertujuan untuk mengetahui sebaran data yang ada pada masing-masing populasi (kelas) sehingga jika data memiliki distribusi yang tidak sentralis (data tidak berbentuk kurva normal) maka data hasil penelitian akan cenderung tidak signifikan pada data olahan selanjutnya dan sebaliknya. Sehingga untuk mengetahuinya penelitian ini melakukan uji normalitas. Pada penelitian ini uji normalitas dianalisis melalui SPSS, dan berikut hasilnya:

Table 3.2. Uji Normalitas melalui SPSS

\begin{tabular}{|c|c|r|r|r|}
\hline Data hasil & Model & \multicolumn{3}{|c|}{ Kolmogorov-Smirnov $^{a}$} \\
\cline { 3 - 5 } belajar & Pembelajaran & Statistic & $d f$ & \multicolumn{1}{c|}{ Sig. } \\
\hline \multirow{3}{*}{ Bhs Indonesia } & model jigsaw & 0,087 & 34 & $0,200^{*}$ \\
& model STAD & 0,139 & 34 & 0,095 \\
& Konvensional & 0,097 & 35 & $0,200^{*}$ \\
\hline
\end{tabular}

*. This is a lower bound of the true significance. 


\section{a. Lilliefors Significance Correction}

Dengan menggunakan kriteria taraf signifikan, maka besarnya sig data hasil belajar puisi pada masing-masing kelompok melalui analisis SPSS dibandingkan dengan taraf signifikan $\alpha=0,05$. Berdasarkan uji normalitas Kolmogorov-Smirnov a diperoleh bahwa harga sig $>\alpha$ yaitu 0,200>0,05 (model jigsaw); 0,095 > 0,05 (model STAD); 0,200 > 0,05 (model konvensional). Dengan demikian dapat disimpulkan bahwa data hasil penelitian ini memiliki distribusi data yang relatif sentralis atau dapat dinyatakan datanya normal. Berikut gambar kenormalan dalam histrogram untuk membuktikan bahwa data yang dianalisis SPSS adalah data yang normal

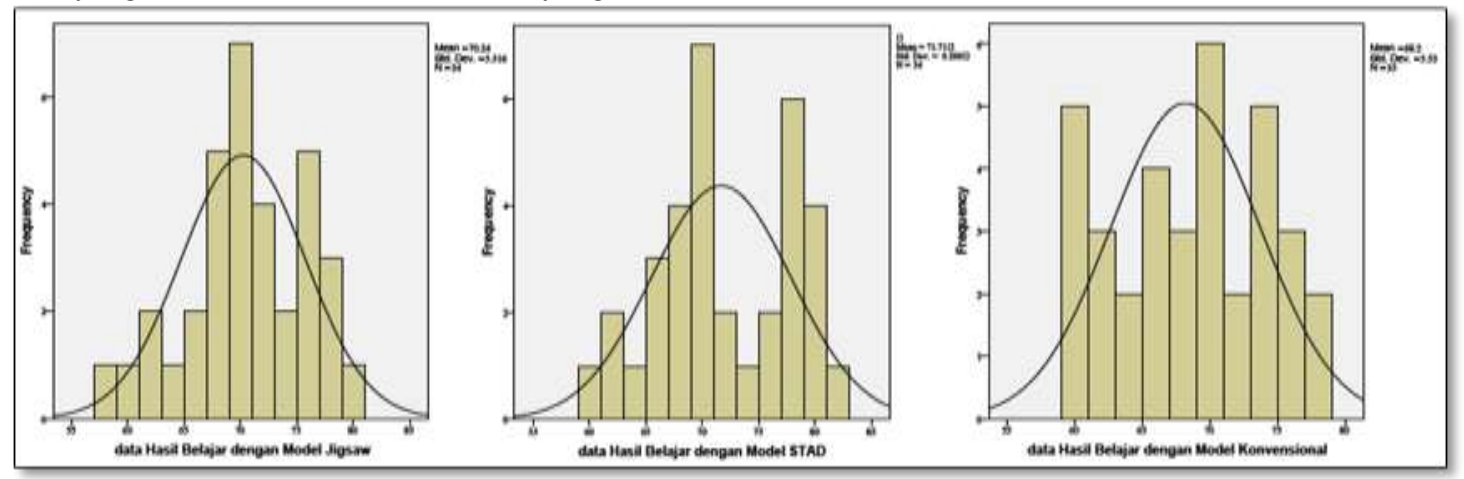

Gambar 3.1. Kenormalan Data Hasil Belajar

\section{b. Uji Homogenitas}

Uji homogenitas dalam penelitian ini bertujuan untuk menggambarkan ragam data yang tersebar pada ketiga kelompok data. Artinya sebaran data antar kelompok dalam penelitian ini akan dicaritahu apakah varians data pada masing-masing kelompok memiliki perbedaan sebaran yang signifikan atau tidak. Sehingga untuk mengetahuinya penelitian ini melakukan uji homogenitas. Pada penelitian ini uji homogenitas dianalisis melalui SPSS, dan berikut hasilnya:

Tabel 3.3. Uji Homogenitas melalui SPSS

\begin{tabular}{|l|l|r|r|r|c|}
\hline \multicolumn{2}{|c|}{ Kriteria } & Levene Statistic & df1 & df2 & Sig. \\
\hline Data hasil belajar & Based on Mean & 0,880 & 2 & 100 & 0,418 \\
Bahasa Indonesia & Based on Median & 0,624 & 2 & 100 & 0,538 \\
& $\begin{array}{l}\text { Based on Median and } \\
\text { with adjusted df } \\
\end{array}$ & 0,624 & 2 & 97,770 & 0,538 \\
& Based on trimmed mean & 0,870 & 2 & 100 & 0,422 \\
\hline
\end{tabular}

Uji homogenitas yang diperoleh melalui analisis SPSS menunjukkan bahwa data hasil belajar antar kelas memiliki harga hitung based on mean sebesar 0,880. Hasil analisis ini digunakan sebab ukuran perbandingan dalam penelitian ini lebih cenderung menggunakan rata-rata dari pada yang lainnya (median atau modus). Oleh karena itu, berdasarkan analisis yang telah dilakukan diperoleh bahwa sig $>\alpha$ yakni 0,418>0,05. Sehingga dapat disimpulkan bahwa varians masing-masing kelas (populasi) diasumsikan sama atau homogen.

\section{c. Uji Hipotesis}

Setelah dilakukan pendeskripsian dan uji persyaratan (uji asumsi) yang secara nyata diperlukan dalam data kuantitatif, maka selanjutnya pembuktian hipotesis yang muncul dari teori/ kerangka pikir yang dikonstruksikan oleh peneliti perlu dilakukan melalui analisis varians (anava satu jalur). Dan telah diperoleh bahwa data hasil penelitian ini adalah normal dan homogen sehingga penggunaan uji $\mathrm{F}$ melalui SPSS ini telah memenuhi kriteria untuk tahap pengujian hipotesis penelitian. Dan berikut hasil analisisnya:

Tabel 3.4. Uji Hipotesis (one-way anova) melalui SPSS

\begin{tabular}{|c|c|c|c|c|c|}
\hline & Sum of Squares & Df & Mean Square & $F$ & Sig. \\
\hline Between Groups & 214,136 & 2 & 107,068 & 3,230 & 0,044 \\
Within Groups & 3314,776 & 100 & 33,148 & & \\
Total & 3528,913 & 102 & & & \\
\hline
\end{tabular}

Berdasarkan hasil anilisis SPSS dapat diketahui bahwa $F_{\text {hitung }}$ sebesar 3,230. Secara teoritis harga tersebut perlu dikonsultasikan dengan harga $F_{\text {tabel. }}$. Namun untuk mengetahui kesimpulan analisis yang dilakukan melalui SPSS maka harga taraf signifikanlah yang akan digunakan. Diperoleh bahwa sig $<\alpha$ yakni $0,044<0,05$ maka dapat disimpulkan bahwa hipotesis yang diterima adalah $\mathrm{H}_{\mathrm{a}}$. Atau dengan 
pernyataan lain bahwa terdapat perbedaan yang signifikan antara model pembelajaran yang digunakan terhadap hasil belajar puisi.

\section{d. Uji Lanjutan}

Uji hipotesis yang telah dilakukan ternyata menerima $\mathrm{H}_{\mathrm{a}}$, dengan hipotesis penelitian yang dibuktikan adalah terdapat perbedaan pengaruh antara model pembelajaran yang digunakan terhadap hasil belajar puisi. Sesuai dengan kriteria hipotesis yang diperoleh maka penelitian ini melakukan analisis lanjutan guna mengetahui pasangan mana yang menyebabkan adanya perbedaan pengaruh model pembelajaran terhadap hasil belajar puisi. Adapun uji lanjutan (pos hoc) yang digunakan adalah uji benferroni, dan dianalisis melalui SPSS berikut ini:

\section{Tabel 3.5. Uji Lanjutan melalui SPSS}

\section{Multiple Comparisons}

Dependent Variable: Data Hasil Belajar Puisi Bonferroni

\begin{tabular}{|c|c|c|c|c|c|c|}
\hline \multirow{2}{*}{$\begin{array}{l}\text { (I) Model } \\
\text { Pembelajaran }\end{array}$} & \multirow{2}{*}{$\begin{array}{l}\text { (J) Model } \\
\text { Pembelajaran }\end{array}$} & \multirow{2}{*}{$\begin{array}{c}\text { Mean } \\
\text { Difference } \\
(\mathrm{I}-\mathrm{J})\end{array}$} & \multirow{2}{*}{$\begin{array}{l}\text { Std. } \\
\text { Error }\end{array}$} & \multirow[t]{2}{*}{ Sig. } & \multicolumn{2}{|c|}{ 95\% Confidence Interval } \\
\hline & & & & & $\begin{array}{l}\text { Lower } \\
\text { Bound }\end{array}$ & $\begin{array}{l}\text { Upper } \\
\text { Bound }\end{array}$ \\
\hline \multirow{2}{*}{ Model Jigsaw } & Model $S T A D$ & -1.471 & 1.396 & 0,884 & -4.87 & 1.93 \\
\hline & Model Konvensional & 2.035 & 1.386 & 0,436 & -1.34 & 5.41 \\
\hline \multirow{2}{*}{ Model $S T A D$} & Model Jigsaw & 1.471 & 1.396 & 0,884 & -1.93 & 4.87 \\
\hline & Model Konvensional & $3.506^{*}$ & 1.386 & 0,039 & .13 & 6.88 \\
\hline Model & Model Jigsaw & -2.035 & 1.386 & 0,436 & -5.41 & 1.34 \\
\hline Konvensional & Model STAD & $-3.506^{*}$ & 1.386 & 0,039 & -6.88 & -0.13 \\
\hline
\end{tabular}

*. The mean difference is significant at the 0.05 level.

Dengan memperhatikan pasangan kelompok yang dianalisis yaitu model jigsaw - STAD, model jigsaw - konvensional dan model STAD - konvensional maka dapat diketahui pasangan manakah yang menyebabkan $\mathrm{H}_{\mathrm{a}}$ diterima. Berdasarkan tabel 3.5. di atas dapat diketahui bahwa harga sig yang diperoleh masing-masing pasangan yaitu 0,884 (jigsaw-STAD); 0,436 (jigsaw-konvensional); dan 0,039 (STADkonvensional). Untuk mengetahui kriteria apa yang dimiliki setiap pasangan maka dibandingkanlah sig dengan $\alpha$. Untuk jigsaw-STAD $(0,884>0,05)$, jigsaw-konvensional $(0,436>0,05)$ dan STADkonvensional $(0,039<0,05)$. Dengan demikian dapat diketahui bahwa pasangan jigsaw-STAD menerima $\mathrm{H}_{\mathrm{o}}$, pasangan jigsaw-konvensional menerima $\mathrm{H}_{0}$ dan hanya pasangan STAD-konvensional saja yang menerima $\mathrm{H}_{\mathrm{a}}$. Jadi dapat disimpulkan bahwa pada pasangan jigsaw-STAD tidak terdapat perbedaan pengaruh model pembelajaran yang signifikan terhadap hasil belajar puisi, pasangan jigsaw-konvesional juga diperoleh kesimpulan bahwa tidak terdapat perbedaan pengaruh model pembelajaran yang signifikan terhadap hasil belajar puisi, dan pasangan STAD-konvensional menyimpulkan bahwa terdapat perbedaan pengaruh model pembelajaran yang signifikan terhadap hasil belajar puisi.

\subsection{Pembahasan Hasil Penelitian}

Penelitian ini dilaksanakan di SMP Negeri 19 Medan dengan 103 sampel penelitian siswa kelas VIII tahun pelajaran 2018/2019 dari 3 kelas. Secara rinci, pembahasan hasil belajar puisi dengan menggunakan model jigsaw, Stad dan sebagai pembanding adalah model konvensional tersebut dapat diuraikan sebagai berikut.

Setelah melaksanakan prosedur penelitian seperti uji normalitas, homogenitas dan pengujian hipotesis, akhirnya dapat ditemukan hasil penelitian. Dari hasil perhitungan melalui SPSS di atas, maka dapat diketahui nilai hasil belajar puisi dengan menggunakan model tersebut. Pada penggunakan model jigsaw di kelas VIII-1 diperoleh nilai rata-rata 70,24. Pada penggunaan model Stad di kelas VIII-2 diperoleh nilai rata-rata 71,71 dan sedangkan pada penggunaan model konvensional di kelas VIII-3 diperoleh nilai rata-ratanya ialah 68,20. Maka dari penerapan model tersebut, hasil belajar yang rataratanya paling rendah adalah model pembelajaran konvensional.

Pada uji normalitas, nilai yang diperoleh dari hasil belajar puisi dari ketiga model tersebut menunjukkan hasil yang signifikan. Dengan menggunakan kriteria taraf signifikan, maka besarnya signifikan data hasil belajar puisi pada masing-masing kelompok melalui analisis SPSS dibandingkan dengan taraf signifikan $\alpha=0,05$. Berdasarkan uji normalitas Kolmogorof -Smirnov diperoleh bahwa harga sig $>\alpha$ yaitu 0,200 >0,05 (model jigsaw), 0,095 >0,05 (model stad), 0,200 > 0,05 (model konvebsional). Dengan demikian dapat disimpulkan bahwa data hasil penelitian tersebut dinyatakan normal.

Pada uji homogenitas yang diperoleh melalui analisis SPSS menunjukkan bahwa data hasil belajar antar kelas memili harga hitung based on mean sebesar 0,880 . Hasil ini digunakan sebab ukuran 
perbandingan dalam penelitian ini lebih cenderung menggunakan rata-rata dari pada yang lainnya (median atau modus). Oleh karena itu, berdasarkan analisis yang telah dilakukan diperoleh bahwa sig $>\alpha$ yakni $0,418>0,05$. Sehingga dapat disimpulkan bahwa varians masing-masing kelas (populasi) diasumsikan sama atau homogen.

Berdasarkan hasil analisis SPSS dapat diketahui bahwa Fhitung sebesar 3,230. Secara teoritis harga tersebut perlu dikonsultasikan dengan harga Ftabel. Untuk mengetahui kesimpulan analisis yang dilakukan melalui SPSS maka harga taraf signifikanlah yang akan digunakan. Diperoleh bahwa sig $<\alpha$ yakni $0,044<0,05$ maka dapat disimpulkan bahwa hipotesis yang diterima adalah $\mathrm{Ha}$ atau dengan pernyataan lain bahwa terdapat perbedaan yang signifikan antara model pembelajaran yang digunakan terhadap hasil belajar Puisi.

Berdasarkan tabel 3.5 diatas dapat diketahui bahwa harga sig yang diperoleh masing-masing pasangan yaitu 0,884 (Jigsaw-Stad), 0,436 (Jigsaw-Konvensional) dan 0,039 (Stad-Konvensional). Untuk mengetahui kriteria apa yang dimiliki setiap pasangan maka dibandingkanlah sig dengan $\alpha$. Untuk Jigsaw-Stad $(0,884>0,05)$, Jigsaw- konvensional $(0,436>0,05)$ dan pasangan Stad-konvensional $(0,039$ $<0,05)$. Dengan demikian dapat diketahui bahwa pasangan Jigsaw-Stad menerima H0, pasangan Jigsaw Konvensional menerima H0 dan hanya pasangan Stad-konvensional saja yang menerima Ha.

Jadi dapat disimpulkan bahwa pada pasangan Jigsaw-Stad tidak terdapat perbedaan pengaruh model pembelajaran yang signifikan terhadap hasil belajar puisi, pasangan Jigsaw-konvensional juga diperoleh kesimpulan bahwa tidak terdapat perbedaan pengaruh model pembelajaran yang signifikan terhadap hasil belajar puisi, dan pasangan Stad-konvensionallah terdapat perbedaan pengaruh model pembelajaran yang signifikan terhadap hasil belajar puisi.

\section{KESIMPULAN}

Berdasarkan hasil analisis data dan pembahasan yang telah diuraikan sebelumnya, maka dapat diambil kesimpulan sebagai berikut:

1. Tidak terdapat perbedaan pengaruh model pembelajaran Jigsaw-Sttad yang signifikan terhadap hasil belajar puisi. siswa yang belajar dengan menerapkan dengan model Jigsaw.

2. Pada model Jigsaw-konvensional tidak terdapat perbedaan pengaruh model pembelajaran yang signifikan terhadap hasil belajar puisi.

3. Ada perbedaan pengaruh model pembelajaran yang signifikan antara Stad-konvensional terhadap hasil belajar puisi.

Hasil penelitian tersebut di atas menunjukkan bahwa dalam pelaksanaan pembelajaran dengan menggunakan model pembelajaran kooperatif tipe stad mempengaruhi pencapaian hasil belajar puisi. Selanjutnya dengan menggunakan model pembelajaran kooperatif tipe Jigsaw siswa lebih mempunyai perspektif tentang belajar dan kerjasama. Hal ini disebabkan kesederhanaan model pembelajaran kooperatif tipe stad sehingga memudahkan bagi guru untuk menggunakan model tersebut dan memudahkan bagi siswa untuk memahami dan melaksanakan. Untuk itu seyoganya penggunaan model pembelajaran kooperatif khususnya tipe stad perlu diterapkan dalam kegiatan belajar mengajar di kelas, karena penggunaan model pembelajaran kooperatif tipe stad berpengaruh secara signifikan dalam upaya meningkatkan hasil pencapaian hasil belajar siswa.

\section{Saran}

Berdasarkan hasil penelitian, peneliti juga menyampaikan beberapa saran sebagai berikut:

1. Guru Bidang studi Bahasa Indonesia di SMP Negeri 19 medan, dalam melaksanakan kegiatan pembelajaran sebaiknya menggunakan model pembelajaran Stad, hal ini karena dari hasil penelitian menunjukkan bahwa model pembelajaran Stad lebih baik dari model pembelajaran jigsaw .

2. Pembelajaran Bahasa Indonesia, guru Bahasa indonesia di SMP Negeri 19 Medan:

a. Merancang model pembelajaran yang menarik dan menyenangkan dengan menerapkan model pembelajaran stad sehingga dapat membantu siswa untuk menguasai materi pelajaran dengan baik.

b. Menumbuhkan semangat dan gairah belajar siswa melalui model pembelajaran stad.

c. Memberikan kesempatan kepada siswa untuk mau melakukan, mencoba dan menyelesaikan persoalan yang berkaitan dengan Bahasa Indonesia agar siswa dapat meningkatkan rasa percaya dirinya.

d. Mengendalikan suasana pembelajaran agar pembelajaran tetap dalam suasana yang menyenangkan.

e. Membentuk kelompok yang beranggotakan sesuai dengan jumlah permasalahan yang akan dibahas agar lebih mengoptimalkan keterlibatan siswa dalam kegiatan diskusi kelompok.

3. Banyak variabel penelitian yang belum diungkap secara mendalam dalam penelitian ini, misalnya dalam hal pengukuran hasil belajar hanya mengukur aspek kognitif mahasiswa. Oleh karena itu 
disarankan untuk diadakan penelitian lebih lanjut yang bertujuan untuk meningkatkan aspek afektif dan psikomotor siswa sehingga akan lebih lengkap dalam menilai kompetensi yang dimiliki oleh siswa.

\section{DAFTAR PUSTAKA}

Nurgiyantoro, Burhan. 2009. Teori Pengkajian Fiksi. Yogyakarta: Gajah Mada University Press.

Sumardjo, Jakob \& amp; Saini K.M.1997. Apresiasi Kesusastraan. Jakarta: PT Gramedia.

Sugihastuti. 2007. Teori Apresiasi Sastra. Yogyakarta: Pustaka Pelajar.

Istarani. 2017. 58 Model Pembelajaran Inovatif. Medan: Media Persada.

Priansa, DJ. 2017. Pengembangan Strategi Dan Model Pembelajaran. Bandung: CV Pustaka Setia.

Aminuddin. 2015. Pengantar Apresiasi Karya Sastra. Bandung: Sinar Baru Algensindo.

Sugiyono. 2014. Metode Penelitian Pendidikan Pendekatan Kuantitatif, Kualitatif Dan R\&D. Bandung: Alfabeta.

Muhammad, A, G. 2015. Statistika Pendidikan, Bidang Pendidikan, Psikologi Dan Sosial. Yogyakarta. Parama Publishing.

https://jurnal.unimed.ac.id/2012/index.php/inpafi/article/viewFile/1975/7919

https://eprints.uny.ac.id/10164/1/JURNAL\%20PENELITIAN.pdf

http://jurnal.uns.ac.id/GeoEco/article/download/8924/7940

http://repository.uinjkt.ac.id/dspace/bitstream/123456789/24410/1/ANGGA\%20PRANATA-FITK.pdf http://repositori.uin-alauddin.ac.id/5245/1/ERNAWATI\%20JABBAR.pdf

http://ejournal.upi.edu//index.php/JER/article/download/9619/5928

https://www.neliti.com/id/publications/76839/pengaruh-pembelajaran-kooperatif-tipe-jigsaw-terhadapkemampuan-membaca-teks-bah http://jurnal.uns.ac.id/GeoEco/article/view/8924

http://digilib.unila.ac.id/26829/2/SKRIPSI\%20TANPA\%20BAB\%20PEMBAHASAN.pdf http://digilib.unila.ac.id/32445/3/3.\%20SKRIPSI\%20FULL\%20TANPA\%20BAB\%20PEMBAHASAN.p df

Indonesia, U. P., \& UNPRI, M. (2019, March). Prosiding Seminar Nasional Fakultas Keguruan dan Ilmu Pendidikan. In Seminar Nasional UNPRI (Vol. 1, No. 1).

Pardede, O. B. (2013). Pengaruh model pembelajaran dan berpikir kreatif siswa terhadap hasil belajar fisika siswa SMP Negeri 30 Medan (Doctoral dissertation, UNIMED).

Sianturi, G. G. N., Akbar, S., \& Pardede, O. B. (2019). Meningkat Kemampuan Menulis Teks Berita Dengan Model Pembelajaran Kooperatif Tipe Stad (Student Team Achievement Divisions) Oleh Siswa Kelas VIII-A SMP Dharma Pancasila Medan Tahun Pelajaran 2018/2019. Tapanuli Journals, 1(2), 357-361.

Sitompul, E. S., Syahfitri, D., \& Pardede, O. B. (2019). Peningkatan Kemampuan Mengidentifikasi Struktur Teks Eksemplum Dengan Menggunakan Model Pembelajaran Think Pair And Share Pada Siswa Kelas Viii-3 Smp Negeri 1 Tigapanah Tahun Pelajaran 2018/2019. Tapanuli Journals, 1(2), 351-356. 